\title{
LONGITUDINAL EFFECT OF THE PUNAV PREVENTION PROGRAM ON NORMATIVE BELIEFS AND ALCOHOL USE AMONG UNIVERSITY STUDENTS
}

\author{
Ondrej Kalina, Lucia Barbierik, \& Jozef Benka \\ Department of Educational Psychology \& Health Psychology,Faculty of Arts,PJ Safarik \\ University in Kosice (Slovakia)
}

\begin{abstract}
The universal Prevention Program of Substance Use among University Students (PUNAV) is based on the strategy of correcting normative beliefs (NBs) regarding alcohol use. The current research shown that NBs are a significant factor in relation to alcohol consumption. This study has explored whether a change of NBs is associated with a decrease of alcohol use among university students.

The data used in this study were collected before the implementation of PUNAV in September 2018 $(\mathrm{N}=137$, Mage $=21.9,77 \%$ women $)$ and 18 months later after the implementation of the program in March 2020 ( $\mathrm{N}=54,77 \%$ women). Participants provided information on alcohol consumption, alcohol dependence, alcohol harmful use and descriptive NBs regarding alcohol consumption. The level of NBs at T2 was subtracted from level of NB at T1 (T1 - T2) to identify changes in NBs over time. Using SPSS 21, a linear regression model which controlled for the level of the outcome variables at $\mathrm{T} 1$ and observed changes in NBs were used to predict the outcome variables measured at T2.

Alcohol consumption and NBs after PUNAV decreased alcohol consumption but increased the dependence and alcohol harmful consequences. The regression model, which controlled for alcohol use at T1, showed that a significant change in NBs was negatively associated with alcohol consumption at $\mathrm{T} 2$. The findings have in general shown that the observed changes in NBs (corrected NBs) were more likely to decrease alcohol consumption among university students.
\end{abstract}

Keywords: Prevention, university students, alcohol use, normative beliefs.

\section{Introduction}

The Universal Prevention of Substance and AIDS Prevention Program (PUNAV) among University Students is a 24-hour experiential learning course, primarily aimed at developing the competencies of future prevention trainers. The program uses a strategy of disseminating information, developing life skills and resisting social impact. Strategy of disseminating information is based on workshops with professionals in psychological, pedagogical, medical and legal-criminal aspects of prevention. Strategy of social influence and development of life skills are normally experienced as 12 two-hour long interactive lectures in three-day long training. The training is realized under the supervision of experienced lecturers and includes topics as normative beliefs, refusal skills, assertiveness, decision-making, coping strategies, goal setting. It has been found that after the implementation of the program a significant change in perceived lecturer competencies occurred at the level of overall capabilities as well as at the level of individual competences. Participants who had completed the program considered themselves to be more capable of realizing experiential group activities, promoting assertiveness in students, creative thinking, critical thinking, self-control and expressing emotions but also of providing information on different types of addictive substances (Dobrowolska Kulanová, Štefaňáková, \& Orosová, 2019). Thus, it might help future teachers, social workers, school psychologists or prevention co-ordinators to improve their skills in prevention of risk behavior. Another perspective of effectiveness of the PUNAV program lies in its effect on risk behavior of students themselves. One of the basic strategies used in the program is to try to correct normative beliefs about risky behavior. Normative beliefs about risky behavior, when overestimated, might predict risky behavior (Stone et al, 2012; Brutovská, Orosová, Kalina, 2016). It has been shown that there is a lower level of normative beliefs concerning several forms of risk behavior among those who completed the PUNAV program (Kulanová et al., 2018). It has also been found that the risk behavior regarding alcohol use has been decreased among men instantly after the participation on the 
program (Dobrowolska-Kulanová, Štefaňáková, Orosová, 2019). The importance of the level of normative beliefs about alcohol use in the alcohol consumption has been also outlined by the previously mentioned research study. The current study however addresses the longitudinal effect of the PUNAV program on risk behavior (alcohol use, alcohol dependence and alcohol harmful consequences) with the specific role of normative beliefs change overtime. Therefore, this study aims to explore whether a change of NBs $(\mathrm{T} 1-\mathrm{T} 2)$ is associated with a decrease of alcohol use among university students.

\section{Methods}

\subsection{Sample}

We compared students who complete and did not complete PUNAV prevention program. The total number of involved students was 249 (Mage $=21.66, \mathrm{SD}=2.12$ ), of which 137 students (Mage $=21.9,77 \%$ women) completed the PUNAV (experimental group) and 112 students (control group), (Mage $=22.17, \mathrm{SD}=2.48)$. Online data collection was used. The first data collection (T1) for both groups started before the implementation of PUNAV in September 2018 and second data collection (T2) took place 18 months later after the implementation of the program in March 2020.

\subsection{Measures}

Descriptive normative beliefs regarding alcohol use were measured by the question: "How many students at your university do you think drink alcohol regularly?" Four-point scale was used (from 1-nobody to 4-most of them). The level of NBs at T2 was subtracted from level of NB at T1 (T1 - T2) to identify changes in NBs over time. The Cronbach's alpha was 0.66.

Alcohol consumption was measured by the Alcohol Use Disorders Identification Test (AUDIT) AUDIT (Babor, Eiddle, Saunders, \& Monteiro, 2001). This is a 10-item alcohol screening test which detects risky drinking. Three types of outcome measures were used as proposed in AUDIT: (1) hazardous alcohol use (conceptualized in the current study as alcohol consumption); (2) dependence symptoms and (3) harmful alcohol use. Hazardous alcohol use - 3 items (frequency of drinking, typical quantity, frequency of heavy drinking) was evaluated on a 5-point scale from 0 to 4; Dependence symptoms - 3 items (impaired control over drinking, increased salience of drinking, morning drinking) evaluated on a 5-point scale from 0 to 4; Harmful alcohol use - 4 items (guilt after drinking, blackouts, alcohol-related injuries, others concerned about drinking). The sum score ranges from 0-12 for hazardous alcohol use and for dependency symptoms and from 0-16 for harmful alcohol use. A higher value in each domain represents a higher level of use or symptoms. Cronbach's alphas ranged from 0.67 to 0.72 .

\subsection{Statistical analyses}

Firstly, we selected only those respondents which completely answered the questionnaire regarding problem behavior and other explored variables at T1 and T2. After that using regression models we explored whether a change of NBs (T1 - T2) is associated with a decrease of alcohol use among university students in three different alcohol use patters - (1) alcohol consumption; (2) dependence symptoms and (3) harmful alcohol use.

\section{Results}

As shown in Table 1, alcohol consumption and normative beliefs decreased in experimental group. Interestingly, dependence symptoms and harmful alcohol use after 18 months increased. We may assume that those students which initially drinks more due to several reasons (e.g. no parental supervision, overestimated peers drinking etc.) are more likely to be prone to alcohol norms correction program that those which are more likely to be prone to dependence and harmful use. As it was expected the levels of normative believes decreased in experimental group - Table 2. The amount of such decline was significantly associated with decrease of alcohol use in experimental group but not in control group.

\section{Discussion and conclusion}

The results of this study indicate that norms correction may have a significant impact on alcohol use among young students. Our results are in line with previous studies (Brutovska, Orosova, Kalina, \& Sebena, 2015; Helmer et al., 2016) which supports the protective effects of alcohol norms correction on actual alcohol use. The research findings can also be used by the developing the prevention and intervention programs. It is well-known that descriptive normative beliefs largely contribute to alcohol use (Stone et al., 2012) and that making descriptive normative beliefs more accurate lead to a decrease in alcohol use (Moreira et al., 2010). 
Table 1. Descriptive characteristic of alcohol use and normative beliefs.

\begin{tabular}{lcccccccc}
\hline & Alcohol consumption & \multicolumn{2}{c}{ Dependence } & \multicolumn{2}{c}{ Harmful use } & \multicolumn{2}{c}{ Normative beliefs } \\
\hline & \multicolumn{2}{c}{$\mathrm{M}(\mathrm{SD})$} & \multicolumn{2}{c}{$\mathrm{M}(\mathrm{SD})$} & \multicolumn{2}{c}{$\mathrm{M}(\mathrm{SD})$} & \multicolumn{2}{c}{$\mathrm{M}(\mathrm{SD})$} \\
& $\mathrm{T} 1$ & $\mathrm{~T} 2$ & $\mathrm{~T} 1$ & $\mathrm{~T} 2$ & $\mathrm{~T} 1$ & $\mathrm{~T} 2$ & $\mathrm{~T} 1$ & $\mathrm{~T} 2$ \\
Experiment group & $7.1(2.24)$ & $6.6(2.11)$ & $3.5(1.15)$ & $4.1(2.01)$ & $5.2(1.61)$ & $5.4(2.22)$ & $3.5(0.68)$ & $3.1(0.68)$ \\
\hline Control group & $7.3(2.35)$ & $7.1(2.61)$ & $3.6(1.39)$ & $3.8(1.30)$ & $5.42 .38)$ & $5.8(2.03)$ & $3.2(0.78)$ & $3.2(0.75)$ \\
\hline
\end{tabular}

Table 2. Regression models predicting harmful alcohol consumption.

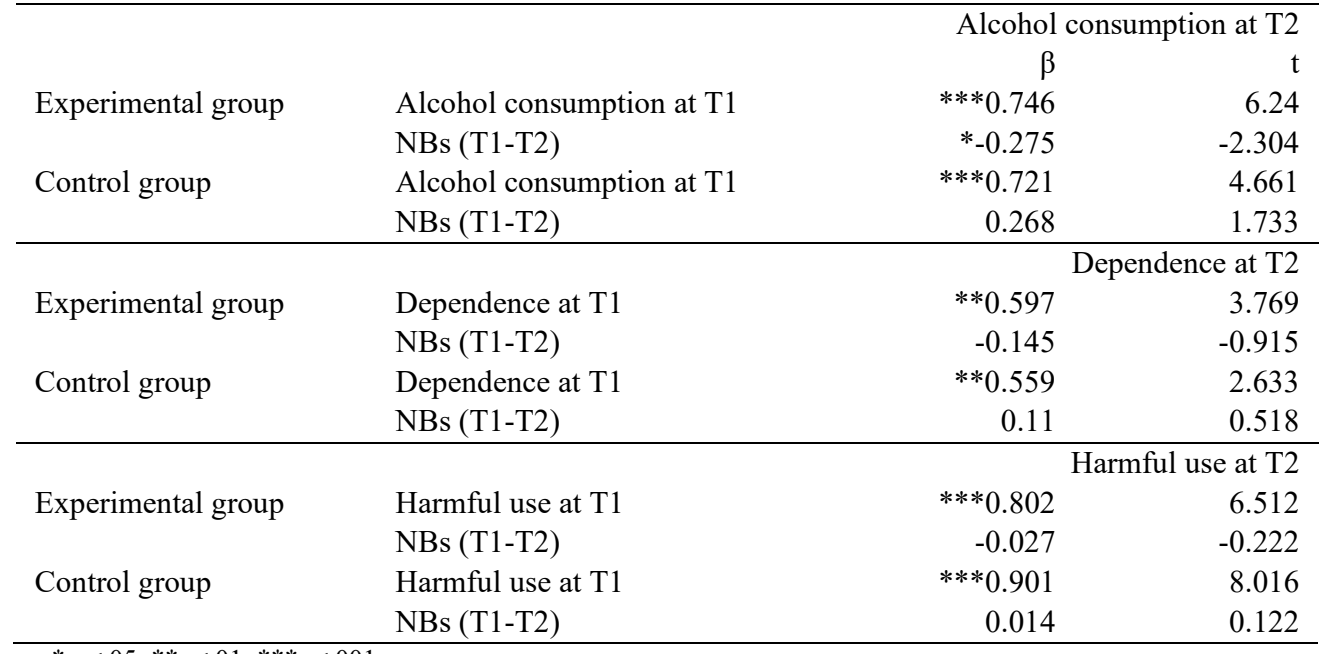

\section{Acknowledgements}

This work was supported by the scientific grant agency of the Ministry of Education, Science, Research and Sport of the Slovak Republic and of Slovak Academy of Sciences under contract no. VEGA 1/0371/20 and by the Slovak Research and Development Agency under the contract no. APVV-15-0662.

\section{References}

Babor, T., Eiddle, J.H., Saunders, J., \& Monteiro M. (2001). The alcohol use disorders identification test Guidelines for use in primary care - Second Edition. World Health Organization: Department of Mental Health and Substance Dependence.

Brutovská, M., Orosová, O., \& Kalina, O. (2016). Normatívne presvedčenia ako moderátor vztahu postoja a konzumácie alkoholu u slovenských vysokoškolákov. Českoslovenksá psychologie, 60, 266-277.

Dobrowolska- Kulanová, M., Štefaňáková, M., \& Orosová, O. (2019). Lektorské kompetencie vysokoškolákov v programe PUNAV. In: Šejvl, J. (Ed.) Kvalita v prevenci je nejlepší investicí do budoucnosti: Reflexe tvorby a vývoje politiky kvality. http://www.pprch.cz/d/doc_file_428_a7d1e139dd622bc2b5854714f9695a8a_pdf/Sbornikkonference-2019.pdf

Dobrowolska-Kulanová, M., Štefaňáková, M., \& Orosová, O. (2019). Effectiveness of the universal substance use prevention program on alcohol consumption among adults. European Journal of Public Health, 29, 554.

Helmer, S.M., Sebena, R., McAlaney, J., Petkeviciene, J., Salonna, F., Lukács, A., \& Mikolajczyk, R.T. (2016). Perception of High Alcohol Use of Peers Is Associated With High Personal Alcohol Use in First-Year University Students in Three Central and Eastern European Countries. Substance Use \& Misuse, 51(9), 1224-1231. https://doi: 10.3109/10826084.2016.1162810

Kulanová, M., Štefaňáková, M., Orosová, O., \& Hricová, L. (2018). Vzdelávanie v prevencii medzi vysokoškolákmi. Adiktologie v preventivní a léčebné praxi, 1, 201.

Moreira, M.T., Smith, L., \& Foxcroft, D. (2010). Social norms interventions to reduce alcohol misuse in University or College students. Retrieved from http://summaries.cochrane.org/CD006748/socialnorms-interventions-to-reduce-alcohol-misuse-in-university-and-college-students.

Stone, A., Becker, L. G., Huber, A. M., \& Catalano, R. F. (2012). Review of risk and protective factors of substance use and problem use in emerging adulthood. Addictive Behaviors, 37,747-775. 